\title{
Pengaruh Jenis dan Konsentrasi Bahan Tambahan Terhadap Pertumbuhan Miselium Jamur Paha Ayam (Coprinus comatus)
}

\author{
Wahyu Dwi Saputra, Nuniek Ina Ratnaningtyas*, Aris Mumpuni \\ Fakultas Biologi, Universitas Jenderal Soedirman \\ Jalan dr. Suparno 63 Purwokerto 53122 \\ Email: nuniek165@yahoo.com
}

Rekam Jejak Artikel:

Diterima : 29/08/2019

Disetujui : 02/06/2020

\begin{abstract}
Coprinus comatus is one of the potential edible mushrooms for commercial cultivation. $C$. comatus is a group of edible and medicinal mushrooms. The body of $C$. comatus contains antioxidants and severalessential amino acids. C. comatus mushrooms grow optimally on medium with supplements. The addition of supplements into the medium aims to provide the nutrients that mushrooms need. Supplements are added in certain amounts. This study aims to determine the optimal combination of supplement types and supplement concentrations for $C$. comatus growth. The research was conducted with an experimental method using a completely randomized design factorial pattem with two test factors namely the type and dosage of supplements. Supplements used are rice bran (bran), ho miny (ampok), wheat bran (polar), and whole wheat flour. The supplementary concentration used are $0 \%, 5 \%, 10 \%, 15 \%$, and $20 \%$. The results obtained from this study are the addition of supplements with different doses significantly affect the micelial growth of $C$. comatus. A good supplement for growing C. comatus is hominy and rice bran. The optimal concentration for the growth of $C$. comatus mycelium is hominy with a concentration of $5 \%$ and rice bran with a concentration of $15 \%$.
\end{abstract}

Keywords: Coprinus comatus, mycelial growth rate, supplement addition.

\begin{abstract}
Abstrak
Coprinus comatus merupakan salah satu jamur pangan yang potensial untuk dibudidayakan secara komersial. Jamur $C$. comatus termasuk ke dalam jamur edible dan medicinal. Tubuh buah $C$. comatus mengandung antioksidan dan beberapa asam amino esensial. Jamur $C$. comatus tumbuh optimal pada medium yang mengandung suplemen. penambahan suplemen pada medium tanam jamur bertujuan untuk memberikan nutrisi yang dibutuhkan jamur. Suplemen ditambahkan dengan jumlah tertentu. Penelitian ini bertujuan untuk mengetahui kombinasi jenis suplemen dan konsentrasi suplemen yang optimal untuk pertumbuhan jamur $C$. comatus. Penelitian dilakukan dengan metode eksperimental menggunakan Rancangan Acak Lengkap pola Faktorial dengan dua faktor uji yaitu jenis dan konsentrasi suplemen. Suplemen yangdigunakan yaitu dedak padi (bekatul), dedak jagung (ampok), dedak gandum (polar), dan tepung gandum. Konsentrasi suplemen yang digunakan yaitu $0 \%, 5 \%, 10 \%, 15 \%$, dan $20 \%$. Hasil yang didapat dari penelitian ini yaitu penambahan suplemen dengan Konsentrasi berbeda berpengaruh nyata terhadap pertumbuhan miselium jamur $C$. comatus. Suplemen yangbaik untuk menumbuhkan jamur $C$. comatus adalah ampok jagung dan dedak padi. Konsentrasi yang optimal untuk pertumbuhan miselium jamur $C$. comatus adalah dedak jagung dengan konsentrasi 5\% dan dedak padidengan konsentrasi $15 \%$.
\end{abstract}

KataKunci : Coprinus comatus, kecepatan pertumbuhan miselium, penambahan suplemen

\section{PENDAHULUAN}

Budidaya jamur merupakan salah satu agroindustri yang cukup potensial dikembangkan di Indonesia. Proses budidaya jamur berkembang cukup baik, namun ada beberapa jenis yang belum dikembangkan secara masal. Contoh jamur yang belum dikembangkan yaitu Coprinus comatus atau jamur paha ayam. Padahal kandungan nutrisi yang ada pada jamur $C$. comatus bermanfaat bagi kesehatan (Dulay et al., 2014)
Jamur C. comatus tergolong dalam kelas Basidiomycetes, bangsa Agaricales, suku Coprinaceae, memiliki spora berwana hitam. Spora yang berwarna hitam ini merupakan ciri dari jamur yang termasuk dalam suku Coprinaceae. Jamur kelompok Coprinaceae dapat hidup pada seresah kayu, dan dedaunan. Dulay et al. (2014) menyebutkan bahwa C. comatus secara alami dapat ditemukan pada serasah yang mengandung selulosa. Jamur dapat mendegradasi selulosa pada serasah kayu dan 
dedaunan. Enzim yang dihasilkan oleh miselium jamur digunakan untuk mendegradasi lignin dan selulosa menjadi glukosa.

Faktor yang mempengaruhi keberhasilan budidaya jamur salah satunya adalah medium tanam yang digunakan. Medium tanam jamur merupakan campuran bahan yang mengandung nutrisi untuk pertumbuhan jamur. Bahan utama pembuatan medium tanam adalah serbuk kayu. Bahan lain yang diperlukan dalam pembuatan medium tanam jamur adalah suplemen, kapur $\left(\mathrm{CaCO}_{3}\right)$, gipsum $\left(\mathrm{CaSO}_{4}\right)$, dan air. Suplemen ditambahkan dalam medium tanam sebagai sumber nutrisi tambahan da lam medium tumbuh jamur. Suplemen yang dapat digunakan antara lain dedak padi (bekatul), dedak jagung (ampok), dan dedak gandum (polar). Kapur $\left(\mathrm{CaCO}_{3}\right)$ berfungsi sebagaipengatur keasaman $(\mathrm{pH})$ medium tanam. Gipsum $\left(\mathrm{CaSO}_{4}\right)$ berfungsi sebagai materi penguat bentuk medium tana $\mathrm{m}$ agar tidak mudah pecah (Piryadi, 2013).

Medium tanam yang digunakan untuk budidaya $C$. comatus yaitu campuran dari jerami dan serbuk kayu (Dulay et al., 2014). Pulp dan limbah kertas juga dapat dijadikan sebagai medium tanam jamur $C$. comatus. Kandungan dalam pulp dan limbah kertas berupa karbon organik dan nitrogen sehingga $C$. comatus dapat tumbuh pada medium tanam pulp dan limbah kertas (Dulay et al. 2012). Kadar karbon dan nitrogen biasa diamati da lam bentuk rasio $\mathrm{C} / \mathrm{N}$. Rasio $\mathrm{C} / \mathrm{N}$ yang tinggi menunjukkan rendahnya penguraian bahan organik dalam medium tanam (Surtinah, 2013). Penelitian ini bertujuan untuk mengetahui kombinasi jenis suplemen dan konsentrasi suplemen yang optimal untuk pertumbuhan jamur $C$. comatus.

\section{MATERI DAN METODE}

\section{Persiapan Media Tanam}

Penelitian dilaksanakan di C.V. Asa Agro Corporation, Cianjur. Medium tanam yang digunakan terdiri campuran serbuk gergaji, suplemen, kapur, dan air. Suplemen terdiri dari campuran dedak padi (bekatul), dedak jagung (ampok), dedak gandum (polar) dan tepung gandum. Serbuk kayu kering ditimbang sesuai berat yang dikehendaki. Bahan medium tanam dicampur dari bagian yang paling sedikit. Kapur dicampur dengan suplemen terlebih dahulu dan diaduk hingga homogen, kemudian dicampur dengan serbuk kayu dan diaduk lagi hingga homogen. Konsentrasi medium yang digunakan 0\%-20\% (Tabel 1).

Tabel 1. Komposisi medium tanam jamur untuk 3 buah baglog

\begin{tabular}{ccccc}
\hline No & Konsentrasi Suplemen & Berat serbuk gergaji (kilogram) & Berat suplemen (kilogram) & Berat kapur (kilogram) \\
\hline 1 & $0 \%$ & 1,53 & 0,00 & 0,03 \\
2 & $5 \%$ & 1,45 & 0,08 & 0,03 \\
3 & $10 \%$ & 1,37 & 0,16 & 0,03 \\
4 & $15 \%$ & 1,29 & 0,23 & 0,03 \\
5 & $20 \%$ & 1,22 & 0,31 & 0,03 \\
\hline
\end{tabular}

Campuran bahan ditambahkan air hingga tingkat kelembapan 60\%. Medium tanam dikemas menggunakan plastik polipropilen (PP) $18 \times 35 \mathrm{~cm}$ dan dipasang collar dan cap. Medium tanam diberi tanda jenis dan konsentrasi suplemen. Medium tanam disterilisasi menggunakan autoklaf selama 40 menit (Piryadi, 2018).

\section{Inokulasi bibit Coprinus comatus (Piryadi, 2018)}

Bibit jamur C. comatus diinokulasikan ke dalam medium tanam sebanyak 5 gram atau hingga memenuhi mulut baglog. Inokulasi dilakukan saat medium tanam telah didiamkan selama 24 jam dan dilakukan dengan cepat untuk menekan tingkat kontaminasi.

\section{Inkubasi medium tanam dan pengukuran kecepatan pertumbuhan miselium (Piryadi, 2018)}

Medium tanam yang sudah diinokulasi bibit kemudian diinkubasi dalam kumbung pemeliharaan selama 60 hari atau hingga medium tanam dipenuhi miselium. Selama proses pemeliharaan diamati juga terjadinya kontaminasi pada medium tanam. Medium tanam yang mengalami kontaminasi dipisahkan dari medium tanam yang tidak terkontaminasi untuk mencegah kontaminan menyerang medium tanam lain. Di akhir masa inkubasi, kecepatan pertumbuhan diukur dengan cara menarik garis lurus dari ujung miselium ke ujung yang lain. Pengukuran dilakukan 4 kali. Selanjutnya dimasukkan ke dalam rumus:

$$
\text { Diameter miseliu }=\frac{D 1+D 2+D 3+D 4}{4}
$$

Keterangan :

D1 = Hasil pengukuran perta ma

D2 = Hasil pengukuran kedua

D3 = Hasil pengukuran ketiga

D4 = Hasil pengukuran keempat

Hasil pengukuran dicatat kemudian dimasukkan ke dalam tabel untuk dikalkulasikan dengan lama waktu inkubasi. 


\section{Analisis data}

Setiap perlakuan diulangan sebanyak 3 kali. Kecepatan pertumbuhan miselium dianalisis secara statistik menggunakan analisis ragam (ANOVA) pada tingkat kepercayaan 95\%. Hasil uji ANOVA dilanjutkan dengan uji Duncan Multiple Range Test (DMRT) dengan instrument IBM SPSS 23.

\section{HASIL DAN PEMBAHASAN}

Penambahan suplemen pada medium tanam jamur dilakukan agar nutrien dalam medium tanam sesuai dengan kebutuhan jamur. Pertumbuhan miselium $C$. comatus akan lebih baik jika nutrien yang dibutuhkan tersedia dalam medium tanam. Nutrien dalam medium tanam dapat diserap oleh miselium secara langsung. Hal ini meningkatkan kecepatan pertumbuhan jamur karena miselium tidak harus mengeluarkan enzim untuk memecah molekul nutrisi yang berukuran besar. Miselium jamur $C$. comatus mengeluarkan enzim ekstraseluler yang dapat memecah molekul kompleks menjadi molekul sederhana yang dapat diserap oleh miselium (Krupodorova et al., 2014). Kecepatan pertumbuhan yang berbeda merupakan pengaruh penambahan suplemen yang berbeda.

Nutrien yang terkandung dalam medium tanam jamur berasal dari bahan-bahan penyusun medium. Selulosa berasal dari serbuk gergaji yang merupakan bahan dasar medium tanam jamur $C$. comatus. Serbuk gergaji yang digunakan da lam medium tanam jamur $C$. comatus adalah kayu sengon (Albizia falcataria (L.) Fosberg). Serbuk gergaji kayu sengon ( $A$. falcataria) mengandung 70- $80 \%$ selulosa (Putra et al., 2018). Trisanti et al. (2018), menyebutkan bahwa kandungan selulosa yang terkandung dalam serbuk kayu sengon adalah

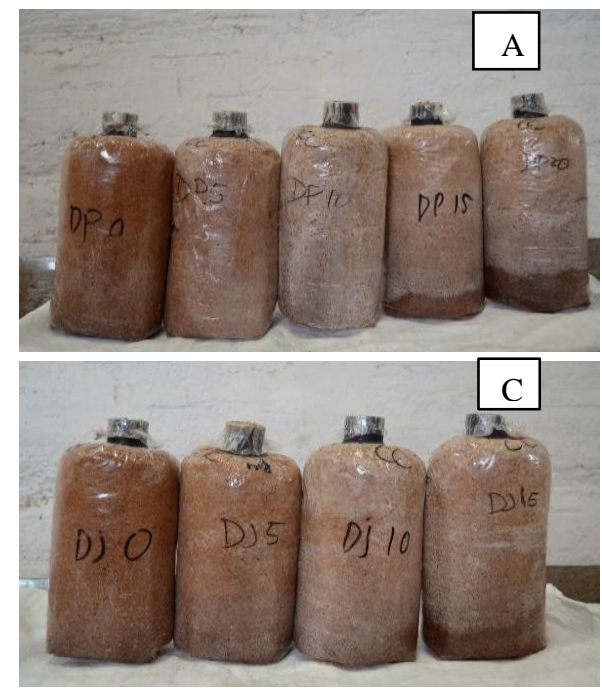

$45,42 \%$, hemiselulosa (21\%), lignin $(26,50 \%)$ dan abu $(7,08 \%)$.

Penambahan suplemen seperti bekatul, ampok jagung, polar, dan tepung gandum dapat meningkatkan kecepatan pertumbuhan miselium jamur $C$. comatus. Nutrisi yang tidak terdapat pada serbuk gergaji dapat tercukupi dari penambahan berbagai jenis suplemen yang digunakan. Bekatul mengandung karbohidrat, protein, serat, abu, dan antioksidan. (Susanto, 2011). Penggunaan suplemen seperti dedak padi, ampok jagung, dan polar baik digunakan karena bahan-bahan tersebut tidak termasuk dalam bahan pangan manusia (Susanti \& Marhaeniyanto, 2007).

Hasil pengamatan secara kualitatif menunjukkan bahwa pertumbuhan miselium jamur C. comatus pada jenis dan konsentrasi suplemen berbeda menunjukkan perbedaan (Gambar 1). Ketebalan miselium C. comatus pada medium tanpa suplemen sangat tipis. Hanya terlihat seperti rambut akar berwarna putih. Namun pada medium dengan suplemen berkonsentrasi tinggi miselium terlihat lebih tebal. Kecepatan pertumbuhan miselium dipengaruhi berbagai macam faktor baik internal maupun eksternal. Faktor internal yang mempengaruhi pertumbuhan miselium antara lain berasal dari medium tanam yang digunakan. Kandungan nutrien dalam medium tanam mempengaruhi kecepatan pertumbuhan miselium jamur. Jenis jamur juga menentukan kecepatan pertumbuhan miselium. Jamur dengan pertumbuhan miselium yang cepat lebih disukai petani karena masa inkubasi lebih pendek. Inkubasi yang pendek mengakibatkan masa panen dapat dilakukan lebih cepat (Piryadi, 2013).

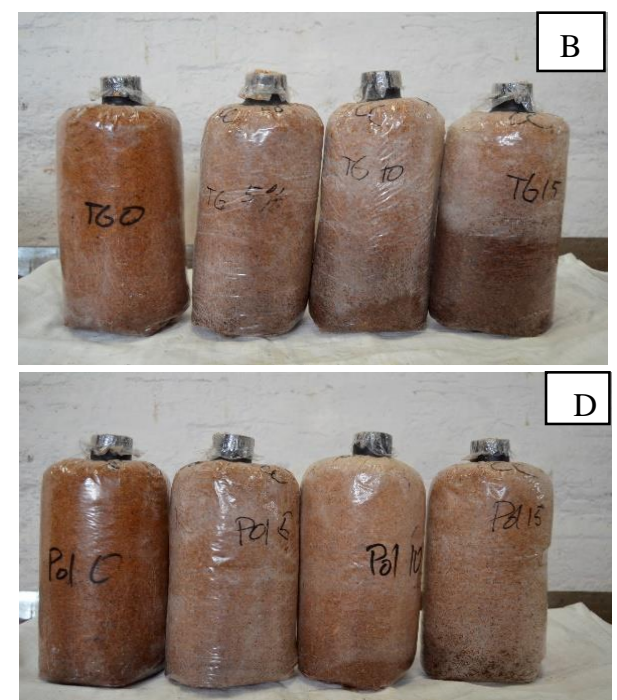

Gambar 1. Kecepatan pertumbuhan miselium jamur C. comatus.dengan jenis dan konsentrasisuplemen berbeda. Keterangan: A : Medium dengan suplemen dedak padi, B : Medium dengan suplemen tepung gandum, $\mathrm{C}$ : Medium dengan suplemen dedak jagung, D : Medium dengan suplemen dedak gandum 
Hasil dari uji analisis ragam menunjukkan bahwa jenis suplemen dan konsentrasi suplemen berpengaruh terhadap pertumbuhan miselium. Suplemen dedak padi dengan konsentrasi $15 \%$ dan dedak jagung dengan konsentrasi $5 \%$ menghasilkan pertumbuhan miselium paling cepat (Tabel 2). Namun, apabila ditinjau dari konsentrasinya suplemen dedak jagung lebih menguntungkan karena hanya membutuhkan konsentrasi 5\% dibandingkan dengan dedak padi yang membutuhkan konsentrasi $15 \%$.

Tabel 2. Duncan Multiple Range Test (DMRT) interaksi jenis dan konsentrasi suplemen terhadap kecepatan pertumbuhan jamur $C$. comatus.

\begin{tabular}{lcc}
\hline Jenis Suplemen & $\begin{array}{c}\text { Konsentrasi } \\
\text { Suplemen }\end{array}$ & *Rerata \\
\hline Dedak Padi & $0 \%$ & $5,337 \mathrm{a}$ \\
\hline Dedak Padi & $5 \%$ & $6,050 \mathrm{def}$ \\
\hline Dedak Padi & $10 \%$ & $5,906 \mathrm{cde}$ \\
\hline Dedak Padi & $15 \%$ & $7,437 \mathrm{i}$ \\
\hline Dedak Padi & $20 \%$ & $5,912 \mathrm{cde}$ \\
\hline Dedak Jagung & $0 \%$ & $6,449 \mathrm{gh}$ \\
\hline Dedak Jagung & $5 \%$ & $7,427 \mathrm{i}$ \\
\hline Dedak Jagung & $10 \%$ & $6,138 \mathrm{defg}$ \\
\hline Dedak Jagung & $15 \%$ & $6,081 \mathrm{defg}$ \\
\hline Dedak Jagung & $20 \%$ & $6,662 \mathrm{~h}$ \\
\hline Dedak Gandum & $0 \%$ & $5,787 \mathrm{cdef}$ \\
\hline Dedak Gandum & $5 \%$ & $6,715 \mathrm{~h}$ \\
\hline Dedak Gandum & $10 \%$ & $6,269 \mathrm{efg}$ \\
\hline Dedak Gandum & $15 \%$ & $6,567 \mathrm{gh}$ \\
\hline Dedak Gandum & $20 \%$ & $5,347 \mathrm{ab}$ \\
\hline Tepung Gandum & $0 \%$ & $6,567 \mathrm{gh}$ \\
\hline Tepung Gandum & $5 \%$ & $5,982 \mathrm{cde}$ \\
\hline Tepung Gandum & $10 \%$ & $6,304 \mathrm{efg}$ \\
\hline Tepung Gandum & $15 \%$ & $5,659 \mathrm{c}$ \\
\hline Tepung Gandum & $20 \%$ & $5,917 \mathrm{cde}$ \\
\hline Keterangan : & & \\
$*$ Angka yang diikuti huruf yang sama tidak berbeda \\
nyata & & \\
\hline
\end{tabular}

Berdasarkan hasil penelitian ini, suplemen dedak jagung. konsentrasi 5\% terpilih sebagai suplemen yang paling baik untuk pertumbuhan miselium. Dedak jagung dihasilkan dari penggilingan jagung kering pada industri tepung. Ampok terdiri atas kandung lembaga, kulit ari, tip cap dan sebagian endosperma sehingga ampok jagung masih mengandung nutrisi yang dibutuhkan untuk menumbuhkan miselium jamur (Muhazalin et al., 2015). Kandungan nutrisi dalam dedak jagung dapat memacu pertumbuhan miselium jamur. Dedak jagung mengandung pati $(56,90 \%)$, serat kasar $(25,20 \%)$, protein $(11,10 \%)$, dan lemak $(5,30 \%)$. (Larson et al., 1993 dalam Muhazalin et al., 2015). Dedak jagung merupakan hasil samping dari penggilingan biji jagung sehingga dari segi ekonomi lebih murah dan menguntungkan apabila digunakan sebagai suplemen.

Konsentrasi suplemen dalam medium perlu diperhatikan pada saat pembuatan medium tanam jamur $C$. comatus. Suplemen berpengaruh terhadap pertumbuhan miselium jamur, namun jumlah suplemen yang tepat akan meningkatkan efisiensi. Biaya pembuatan medium tanam akan lebih rendah jika konsentrasi suplemen yang digunakan tepat. Suplemen yang terlalu banyak akan meningkatkan biaya pembuatan medium tanam sehingga akan meningkatkan modal yang dibutuhkan. Jumlah suplemen yang terlalu banyak juga akan meningkatkan resiko kontaminasi. Kontaminasi dapat dipicu oleh medium tanam yang terlalu subur sehingga jamur kontaminan lebih cepat tumbuhdibandingkan jamur miselium $C$. comatus. (Piryadi, 2013).

Hasil pengamatan kontaminasi menunjukkan bahwa kontaminan yang ditemukan pada medium tanam C. comatus berupa kapang. Kapang tersebut menginfeksi medium tanam secara cepat karena medium tanam mengandung banyak nutrisi. Kecepatan pertumbuhan $C$. comatus tidak mampu bersaing melawan pertumbuhan kapang. Kapang yang ditemukan pada medium tanam C. comatus antara lain Neurospora sp., dan Trichoderma sp. (Gambar 2). Kapang Trichoderma sp. memiliki kecepatan pertumbuhan yang sangat cepat sehingga miselium $C$. comatus tidak bisa tumbuh memenuhi medium yang sudah terkoloni Trichoderma sp. (Frużyńska-Jóźwiak et al., 2011).

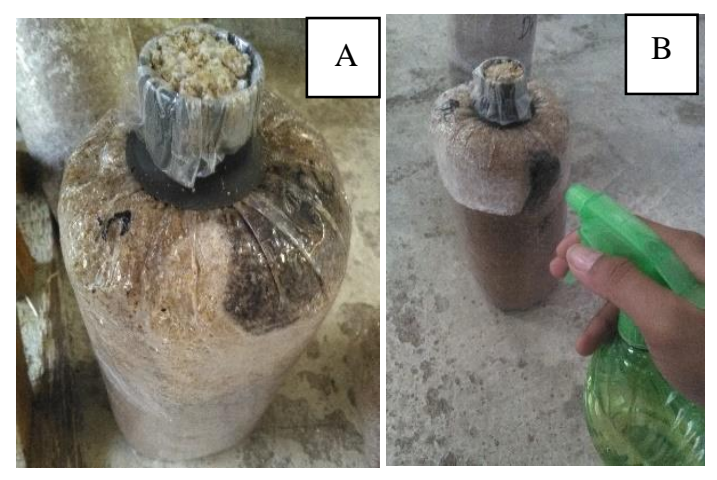

Gambar 2. (A) dan (B) Medium yang terkontaminasi kapang Neurospora sp., dan Trichoderma sp.

Faktor utama yang menyebabkan kontaminasi adalah lingkungan kerja yang kurang aseptis. Kondisi aseptis diperlukan agar medium tanam tidak tercemar oleh adanya patogen maupun organisme lain yang dapat mengganggu pertumbuhan miselium jamur. Kontaminasi dapat disebabkan oleh bakteri, kapang, virus, dan organisme tingkat tinggi 
seperti serangga (Piryadi, 2013). Kondisi lingkungan saat inkubasi juga berpengaruh terhadap tingkat kontaminasi pada medium tanam jamur. Suhu dan kelembapan udara berperan penting dalam proses inkubasi miselium. Miselium $C$. comatus tumbuh optimal pada suhu $23-26^{\circ} \mathrm{C}$ (Jang et al., 2009). Jika suhu dan kelembapan berada pada suhu optimum patogen dan kontaminan maka angka kontaminasi menjadi tinggi. Fluktuasi suhu udara pada siang hari dapat meningkatkan serangan kapang yang dapat mengganggu pertumbuhan miselium jamur $C$. comatus. Suhu udara saat siang hari dapat mencapai $27,5^{\circ} \mathrm{C}$. Menurut Kanti \& Sudiana (2016), Kapang Neurospora sp. tumbuh optimal pada suhu $27^{\circ} \mathrm{C}$. Hal ini menyebabkan terjadinya serangan kapang Neurospora sp. pada medium tanam C. comatus.

\section{SIMPULAN}

Berdasarkan hasil dan pembahasan dapat disimpulkan bahwa terdapat interaksi antara jenis dan konsentrasi suplemen terhadap kecepatan pertumbuhan miselium jamur $C$. comatus. Jenis suplemen yang terbaik adalah ampok jagung dengan konsentrasi 5\% dan dedak padi dengan konsentrasi $15 \%$.

\section{DAFTAR REFERENSI}

Dulay, R.M.R., Gagarin, W.S., Abella, E.A., Kalaw, S.P. Reyes, R.G. 2014. Aseptic Cultivation and Nutrient Compositions of Coprinus comatus (O.F. Müll.) Pers. On Pleurotus Mushroom Spent. J. Microbiol. Biotech. Res., 4(3), pp. 1-7.

Dulay, R.M.R., Parungao, A.G., Kalaw, S.P. \& Reyes, R.G. 2012. Aseptic cultivation of Coprinus comatus (O. F. Mull.) Gray on various pulp and paper wastes. Mycosphere, 3(3), pp. 392-397.

Frużyńska-Jóźwiak, D., Sobieralski, K., Siwulski, M., Spizewski, T., Błaszczyk, L., SasGolak, I. 2011. Effect of Trichoderma Isolates on Yielding of Wild Strains of Coprinus comatus. Journal of Plant Protection Research, Volume 51, pp. 410412.

Jang, M.-J., Lee, Y.H., Lie, J.J. \& Ju, Y.C. 2009. Optimal Conditions for the Mycelial Growth of Coprinus comatus Strains. Mycobiology, 37(2), pp. 103-108.
Kanti, A. \& Sudiana, I. M. 2016. Comparison of Neurospora crassa and Neurospora sitophila for phytase production at various fermentation temperatures. Biodiversitas, 17(2), pp. 769-775.

Krupodorova, T., Ivanova, T. \& Barshteyn, V. 2014. Screening of Extracellular Enzymatic Activity of Macrofungi. Journal of Microbiology, Biotechnology, and Food Sciences, 3(4), pp. 315-318.

Larson, E. M., Stock, R.A., Klopfenstein, T. J., Sindt, M. H., Shain, D. H. 1993. Energy Value of Hominy Feed for Finishing Ruminants. Journal Animal Science, Volume 71, pp. 1092-1099.

Muhazalin, N., Hidayati, L. \& Soekopitojo, S. 2015. Evaluasi Mutu dan Kandungan Serat Nuggets Berbahan Dasar Ampok Jagung. Teknologi dan Kejuruan, 38(2), pp. 157166.

Piryadi, T.U. 2013. Bisnis Jamur Tiram. Jakarta Selatan: AgroMedia Pustaka.

2018. Prosedur Penelitian di CV Asa Agro Corporation [Interview] (1 December 2018).

Putra, A.F.R., Wardenaar, E. \& Husni, H. 2018. Analisa Komponen Kimia Kayu Sengon (Albizia falcataria (L.) Fosberg) Berdasarkan Posisi Ketinggian Batang. Jurnal Hutan Lestari, 6(1), pp. 83-90.

Surtinah. 2013. Pengujian Kandungan Unsur Hara dalam Kompos yang Berasaldari Tanaman Jagung Manis (Zea mays saccharata). Jurnal Ilmiah Pertanian, 11(1), pp. 16-25

Susanti, S. \& Marhaeniyanto, E. 2007. Kecernaan, Retensi Nitrogen dan Hubungannya dengan Produksi Susu pada Sapi Peranakan Kolstein (PFH) yang Diberi Pakan Pollard dan Bekatul. Jurnal Protein, Kecernaan, Retensi Nitrogen, 15(2), pp. 141-148.

Susanto, D. 2011. Potensi Bekatul sebagai Sumber Antioksidan dalam Produk Selai Kacang, Semarang: Prodi Ilmu Gizi, Fakultas Kedokteran, Universitas Diponegoro.

Trisanti, P.N., Setiawan, S., Nura'ini, E. \& Sumarno. 2018. Ekstraksi Selulosa dari Serbuk Gergaji Kayu Sengon Melalui Proses Delignifikasi Alkali Ultrasonik. Jurnal Sains Materi Indonesia, pp. 113119. 